\title{
Assessment of fluoride contamination and distribution: a case study from a rural part of Andhra Pradesh, India
}

\author{
Narsimha Adimalla ${ }^{1,2}$ (1) $\cdot$ Sudarshan Venkatayogi ${ }^{3}$. S. V. G. Das ${ }^{4}$
}

Received: 3 December 2018 / Accepted: 5 May 2019 / Published online: 14 May 2019

(c) The Author(s) 2019

\begin{abstract}
In total, 123 groundwater samples were collected to evaluate the suitability for drinking purpose in a rural part of Andhra Pradesh, India. The groundwater is alkaline in nature and $\mathrm{pH}$ varying from 7.18 to 9.32 with a mean value of 8.36 . The hydrogeochemical analysis reveals that the fluoride concentration varies from 0.4 to $5.8 \mathrm{mg} / \mathrm{L}$ with a mean of $1.98 \mathrm{mg} / \mathrm{L}$. Higher fluoride concentration is found in west-central parts of Markapur region. The villagers have been exposed to the intake of high fluoride-bearing groundwater for the prolonged period and suffering from the deadly disease fluorosis. However, with respect to groundwater chemistry, the fluoride concentration is high in $\mathrm{Na}^{+}-\mathrm{HCO}_{3}{ }^{-}$-type groundwater and low in $\mathrm{Ca}^{2+}-\mathrm{HCO}_{3}{ }^{-}$-type groundwater in the Markapur region. Data plotted in Gibbs diagram show that all groundwater samples fall under rock weathering dominance group with a trend toward the evaporation dominance category. Therefore, rock-water interaction is the primary cause of elevated fluoride in the groundwater of the study region. Furthermore, a significant positive correlation exists between $\mathrm{F}^{-}$and $\mathrm{pH}, \mathrm{HCO}_{3}^{-}$as well as negative correlation exists between $\mathrm{F}^{-}$and $\mathrm{Ca}^{2+}$ and $\mathrm{NO}_{3}^{-}$, which supports that the alkaline nature of water is the main cause for dissolving fluoride-bearing minerals.
\end{abstract}

Keywords Fluoride contamination · Groundwater $\cdot$ Geochemical behavior $\cdot$ Rural area $\cdot$ Andhra Pradesh $\cdot$ India

\section{Introduction}

Groundwater contamination by fluoride is one of the serious problems in the arid and semiarid regions of the world. Particularly in India, a number of people suffer from fluorosis due to intake of high fluoride content through drinking

Electronic supplementary material The online version of this article (https://doi.org/10.1007/s13201-019-0968-y) contains supplementary material, which is available to authorized users.

Narsimha Adimalla

adimallanarsimha@gmail.com

1 School of Environmental Science and Engineering, Chang'an University, No. 126 Yanta Road, Xi' an 710054, Shaanxi, China

2 Key Laboratory of Subsurface Hydrology and Ecological Effects in Arid Region of the Ministry of Education, Chang' an University, No. 126 Yanta Road, Xi'an 710054, Shaanxi, China

3 Department of Applied Geochemistry, University College of Science, Osmania University, Hyderabad 500 007, India

4 Centre for Hydrological Education, Hyderabad 500 010, India water. Approximately, in India, the excessive fluoride in groundwater is noticed in 177 districts covering 21 states, affecting 62 million people, including 6 million children (Adimalla and Venkatayogi 2018; Ayoob and Gupta 2006).

Nearly 200 million people from 25 nations are affected by the deadly disease of fluorosis (Ali et al. 2016; Adimalla and Venkatayogi 2017). Fluorosis-affected regions are reported from China (Li et al. 2018, 2014; Wu et al. 2015), India (Narsimha and Rajitha 2018; Adimalla et al. 2018a, b, c; Narsimha 2018; Narsimha and Sudarshan 2017a, b, 2018a, b; Rao et al. 2014; Subba Rao et al. 2015), Africa (Gizaw 1996), Korea (Kim and Jeong 2005), Mexico (Diaz-Barriga et al. 1997), Kenya (Gikinju et al. 2002) and Nigeria (Gbadebo 2012). A small amount of fluoride is essential to maintain bones and formation of dental enamel (Adimalla and Venkatayogi 2017; Adimalla and Li 2018). However, prolonged intake of high fluoride in drinking water can surely cause fluorosis (Adimalla and Qian 2019a; Narsimha and Sudarshan 2017a; Li et al. 2018). In general, fluoride is released into groundwater from fluorine-bearing minerals such as fluorite, fluorapatite, biotite, apatite, muscovite, hornblende, villiaumite, tremolite, sellaite, cryolite, topaz, fluocerite, yttrofluorite, gagarinite, bastnasite, microlite, sphene, wohlerite, fluormica, epidote, amphibole, 
lepidolite, montmorillonite, kaolinite, pegmatite, mica, clays, villuanite, phosphorite, and some micas weathered from silicates, igneous, and sedimentary rocks, especially shale (Adimalla et al. 2018a; Ayoob and Gupta 2006; Adimalla 2018; Narsimha and Sudarshan 2017a, 2018a, b), and high rates of evaporation and low precipitation in arid and semiarid areas can also contribute to the fluoride enrichment (Adimalla and Venkatayogi 2017, 2018; Subba Rao et al. 2015). However, fluoride is an important element for human health which has certain limits for intake (Rao et al. 2017; Ali et al. 2016; Narsimha and Sudarshan 2017a, b). World Health Organization (WHO 1984) has fixed a safe limit for fluoride from 0.5 to $1.5 \mathrm{mg} / \mathrm{L}$ in drinking water. Moreover, the intake of drinking water with fluoride content less than $0.5 \mathrm{mg} / \mathrm{L}$ can cause tooth decay. Larger than $1.5 \mathrm{mg} / \mathrm{L}$ fluoride content in drinking water is risky for human consumption which leads to dental fluorosis and skeletal fluorosis when exceeds $3 \mathrm{mg} / \mathrm{L}$ (Ayoob and Gupta 2006; Rao et al. 2017; Wu and Sun 2016).

In recent years, a rapid growth of population, industrial development, intense agriculture activity, low rainfall, declining surface water resources, and climate change have caused significant stress on surface/lake water supplies especially in Andhra Pradesh, Telangana states, and other rural parts of the country. Hence, people are forced to depend on groundwater for their daily needs. Eventually, groundwater is becoming more vital water resource primarily for drinking, domestic, and other usages in Markapur provinces. Thus, dental and skeletal health problems are noticed in the Markapur region of Andhra Pradesh. It is reported that the groundwater in areas covering Santhala Moguluru, Guttala madivaram, Vemulapadu, Podili, Kanigiri, Vengayyapalem, Malakonda, Gollapalli, Pasupugallu, Pallamalla, Chandalur and Markapur villages contains fluoride concentration more than the maximum permissible limit of $1.5 \mathrm{mg} / \mathrm{L}$ in Prakasam district, Andhra Pradesh (CGWB 2013). Moreover, Prakasam district is not only known for widespread occurrence of fluorosis but also for the occurrence of a high level of fluoride (Rao et al. 2014; Subba Rao et al. 2015), and few efforts have been made to understand the geochemical processes involved in the occurrence of high fluoride concentration in the groundwater of Markapur region. For this reason, a detailed study was undertaken to understand the geochemistry of fluoride in groundwater and to find the relationship of fluoride with other water quality parameters. This study paves the way to provide baseline information on drinking water safety to researchers/scholars and decision makers for investigating local groundwater problems.

\section{Study area}

The Markapur province is located in the central-western part of the Prakasam district (Fig. 1). The area geographically lies between the $79^{\circ} 10^{\prime} \sim 79^{\circ} 22^{\prime}$ north latitudes and $15^{\circ} 35^{\prime} \sim 15^{\circ} 50^{\prime}$ east longitudes. The vast plains of Markapur and of the adjacent areas are occupied by phyllite/ slate (GSI 1993; GSI-NGRI 2006). Slate, when it is siliceous, stands out as a prominent linear ridge. The slate quarries in the study area represent minor ridges formed by siliceous slates. Mining of slate is the major commercial industry in Markapur. Among the carbonates, cherty dolomite is noticed in the south, where it trends $\mathrm{E}-\mathrm{W}$ and possibly extends into the $\mathrm{N}-\mathrm{E}$ direction. The carbonate and quartzite are the intercalated sequence in the Cumbum Formations. The main geomorphic units, in the study area, with reference to groundwater, are pediplain shallow, denudational hills, structural hills, and a few linear ridges. Pediplain shallow covers most of the area and is moderate to good in groundwater prospects, mainly because of secondary porosity in the form of cleavage. The groundwater prospects are poor in structural hills, denudational hills, and linear ridges. Hydrogeologically, shales and phyllites of the Markaur region under the Cuddapah Supergroup are considered as hard rocks, lacking in primary porosity. They develop secondary porosity through fracturing and weathering over a long period and become water bearing. Groundwater in shales/phyllites occurs in unconfined conditions in the weathered residuum and under semiconfined to confined conditions in the fissures, joints, bedding planes, and fractures (GSI 1993).

Mostly, water table aquifers occur at shallow depths, whereas semiconfined/confined aquifers at greater depths. Shallow aquifers occur within a depth of $20 \mathrm{mbgl}$ (meters below ground level). The ideal sequence of the strata is weathered, semiweathered, and fractured zones. Nature and thickness of these aquifers depend on the depth of weathering, topography, and recharge conditions of the terrain and hence show wide variations in their water-yielding capacity. Groundwater in deeper aquifers occurs under semiconfined or confined conditions. The tectonic disturbance in the eastern fringe of Cuddapah Supergroup has developed deepseated fractures in crystalline rocks and such zones form potential aquifers (GSI 1993). The deeper weathered and fractured rock aquifers are being developed by bore wells generally drilled along lineaments and at other favorable locations. The chemical composition and texture of parent rock not only determine the degree to which it can be weathered but also its reactivity and nature of the resultant product. It is observed, in the study area, that weathered clay residuum formed from argillaceous phyllites, shales, and slates generally do not yield more water. On the other hand, weathered residuum containing more quartz yields more water.

The investigated region falls under semiarid climate condition. The average annual temperature varies from $27^{\circ} \mathrm{C}$ in winter to $45^{\circ} \mathrm{C}$ in summer. The average annual rainfall is $182.9 \mathrm{~mm}$. Southwest monsoon contributes $61 \%$ of the total 


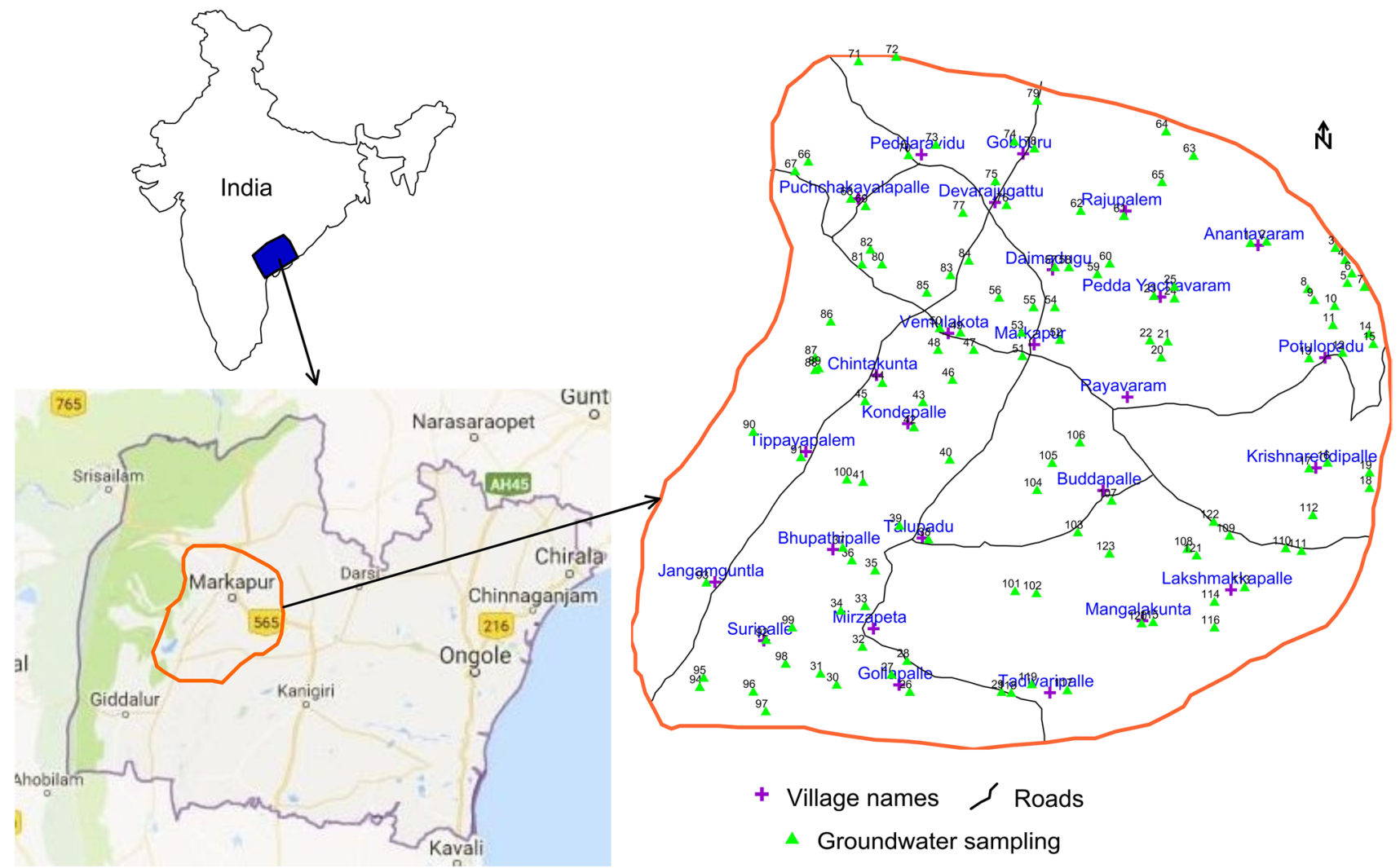

Fig. 1 Location map of the groundwater samples from the Markapur region, India

rainfall. Winds are generally light to moderate, except during the late summer and early southwest monsoon season.

\section{Materials and methods}

Groundwater samples were collected from 123 sampling sites in 1-liter clean polyethylene bottles and labeled with sample ID starting from PDM-1 to PDM-123. The samples were analyzed for anionic and cationic constituents using standard methods APHA (1995). The pH, electrical conductivity (EC), and total dissolved solids (TDS) were analyzed on the site using pH/EC/TDS meter (Hanna HI 9811-5; Narsimha and Sudarshan 2017a). Total hardness (TH) was measured by titration method using standard hydrochloric acid and standard EDTA solution. Calcium $\left(\mathrm{Ca}^{2+}\right)$ and magnesium $\left(\mathrm{Mg}^{2+}\right)$ were determined titrimetrically using standard EDTA. Sodium $\left(\mathrm{Na}^{+}\right)$and potassium $\left(\mathrm{K}^{+}\right)$concentrations were determined using Flame photometer (Systronics, 130). Chloride $\left(\mathrm{Cl}^{-}\right)$was determined by standard $\mathrm{AgNO}_{3}$ titration. Bicarbonate $\left(\mathrm{HCO}_{3}{ }^{-}\right)$and carbonate $\left(\mathrm{CO}_{3}{ }^{2-}\right)$ were determined by titration with $\mathrm{HCl}$. Sulfate $\left(\mathrm{SO}_{4}{ }^{2-}\right)$ and nitrate $\left(\mathrm{NO}_{3}{ }^{-}\right)$were determined by using UV-visible spectrophotometer (Spectronic, 21, BAUSCH and LOMB).
The fluoride concentration in groundwater was determined electrochemically, using Thermo Scientific Orion Star A214 Benchtop pH/ISE meter (9609BNWP fluoride ion-selective electrode) using the USEP ion-selective electrode method. This method is applicable to the measurement of fluoride in drinking water in the concentration range of $0.1-1000 \mathrm{mg} / \mathrm{L}$. Standard fluoride solutions $(0.1-10 \mathrm{mg} / \mathrm{L})$ were prepared from a stock solution (100 mg/L) of sodium fluoride. As per experimental requirement, $2 \mathrm{~mL}$ of total ionic strength adjusting buffer grade III (TISAB III) was added in $20 \mathrm{~mL}$ of water sample. The ion meter was calibrated for a slope of $-59.2 \pm 2$. The composition of TISAB solution was as follows: $58 \mathrm{~g} \mathrm{NaCl}$, $4 \mathrm{~g}$ of CDTA (cyclohexylene diamine tetraacetic acid), and $57 \mathrm{~mL}$ of glacial acetic acid per liter.

Eventually, the accuracy of all chemical analyses was verified by calculating ion-charge balance between cations $\left(\mathrm{Ca}^{2+}, \mathrm{Mg}^{2+}, \mathrm{Na}^{+}\right.$, and $\left.\mathrm{K}^{+}\right)$and anions $\left(\mathrm{HCO}_{3}{ }^{-}, \mathrm{Cl}^{-}\right.$, $\mathrm{SO}_{4}{ }^{2-}, \mathrm{NO}_{3}{ }^{-}$, and $\mathrm{F}^{-}$) as (cations - anions)/(cations + anions) $\times 100$. All the 123 groundwater samples were within the accepted limit of $\pm 10 \%$ (Domenico and Schwartz 1990). 


\section{Results and discussion}

\section{Major ion chemistry}

The analytical results of $\mathrm{pH}$, electrical conductivity (EC), total dissolved solids (TDS), total hardness (TH), calcium $\left(\mathrm{Ca}^{2+}\right)$, magnesium $\left(\mathrm{Mg}^{2+}\right)$, sodium $\left(\mathrm{Na}^{+}\right)$, potassium $\left(\mathrm{K}^{+}\right)$, bicarbonate $\left(\mathrm{HCO}_{3}{ }^{-}\right)$, carbonate $\left(\mathrm{CO}_{3}{ }^{2-}\right)$, sulfate $\left(\mathrm{SO}_{4}{ }^{2-}\right)$, nitrate $\left(\mathrm{NO}_{3}{ }^{-}\right)$, and fluoride $\left(\mathrm{F}^{-}\right)$concentrations of the groundwater samples are presented in Table 1 . The groundwater is mostly alkaline in nature in the Markapur region with $\mathrm{pH}$ concentration ranging from 7.18 to 9.32 and with a mean of 8.36 (Tables 1 and 2). The EC concentration varies between 520 and $4400 \mu \mathrm{S} / \mathrm{cm}$, with a mean of $1451.71 \mu \mathrm{S} / \mathrm{cm}$. The high mean value for EC emphasizes a wide variation in ionic content among different samples, and also it is a measure of a material's ability to conduct an electric current, and the difference of it indicates a wide variation of salts present in the groundwater. TDS concentration of groundwater is varying between 290 and $2640 \mathrm{mg} / \mathrm{L}$, with a mean of $901.91 \mathrm{mg} / \mathrm{L}$. Further, the TDS is classified as fresh, if it is less than $1000 \mathrm{mg} / \mathrm{L}$; brackish, if it is in between 1000 and $10,000 \mathrm{mg} / \mathrm{L}$; saline, if it varies from 10,000 to $100,000 \mathrm{mg} / \mathrm{L}$; and brine, if it is more than $100,000 \mathrm{mg} / \mathrm{L}$. Accordingly, $67 \%$ and $33 \%$ of groundwater fell under fresh and brackish category, respectively, in the present study region. The concentration of $\mathrm{TH}$ (as $\mathrm{CaCO}_{3}$ ) shows wide disparity ranging from 80 to $880 \mathrm{mg} / \mathrm{L}$ with a mean of $255.68 \mathrm{mg} / \mathrm{L}$ (Table 1 ).

Among the cations, $\mathrm{Na}^{+}$is the most dominant in the Markapur groundwater and its concentration ranged from 30 to $850 \mathrm{mg} / \mathrm{L}$, with a mean of $205.47 \mathrm{mg} / \mathrm{L}$ (Table 1). Moreover, one and half times of groundwater samples show higher than the maximum allowable limit of $200 \mathrm{mg} / \mathrm{L}$ in the study region. The higher concentration of sodium may be derived from the dissolution of minerals and soil salts as well as the influence of anthropogenic sources (Todd 1980). The concentration of $\mathrm{Mg}^{2+}$ in the study area groundwater ranged from 40 to $520 \mathrm{mg} / \mathrm{L}$, with a mean of $170.52 \mathrm{mg} / \mathrm{L}$ and about $58 \%$ of groundwater samples exceeded the maximum allowable limit of $150 \mathrm{mg} / \mathrm{L}$ (Table 1). The concentration of $\mathrm{Ca}^{2+}$ ranged between 10 and $360 \mathrm{mg} / \mathrm{L}$, with an average of $85.16 \mathrm{mg} / \mathrm{L}$ recorded in the groundwater of study region which shows 1.8 times higher than the maximum allowable limit $200 \mathrm{mg} / \mathrm{L}$ for drinking purposes. Ferromagnesian minerals and artificial/human activities are the principal sources for higher content of magnesium and calcium in the groundwater (Hem 1991). The $\mathrm{K}^{+}$content ranged from 0.5 to $88 \mathrm{mg} / \mathrm{L}$, with a mean of $7.23 \mathrm{mg} / \mathrm{L}$ in the groundwater of the study region. $\mathrm{K}^{+}$concentration is the least among the major cations in all the sampled groundwater with an estimated percentage mean value of $1.54 \%$. The lower concentration of potassium is generally recorded in groundwater due to its relative greater resistance to weathering, and it is getting out of solution onto clay surfaces leading to its loss (Anim-Gyampo et al. 2018).

A high chloride concentration of groundwater is a result of leaching from the soils and also effect of domestic wastes, domestic effluents, fertilizers, leakages from septic tanks and road salt used to de-ice roads in the winter, and from natural sources such as rainfall, the dissolution of fluid inclusions, and chloride-bearing minerals, which also indicates an index of pollution (Todd 1980; Adimalla and Venkatayogi 2018; Adimalla 2018). In the present study, the concentration of chloride ranges from 25 to $940 \mathrm{mg} / \mathrm{L}$, with a mean of $189.43 \mathrm{mg} / \mathrm{L}$. According to the World Health Organization (WHO 2004) drinking water specifications, the permissible limit in the absence of an alternate source for chloride is $600 \mathrm{mg} / \mathrm{L}$. The results revealed that only $2.4 \%$ of groundwater samples show higher than the $600 \mathrm{mg} / \mathrm{L}$ in the study region. The maximum allowable limit of sulfate for drinking purpose is $400 \mathrm{mg} / \mathrm{L}$ as suggested by the World Health Organization (WHO 2004). The concentration of sulfate is less than the maximum allowable limit of $400 \mathrm{mg} / \mathrm{L}$, which reveals that all the groundwater locations are suitable for drinking purposes in the study region (Table 1). The nitrate concentration varies from 3 to $180 \mathrm{mg} / \mathrm{L}$, with a mean value of $31.28 \mathrm{mg} / \mathrm{L}$ in the study area. Thus, the results indicated four times higher than the maximum allowable limit for nitrate in the study region. In the context of Indian scenario, groundwater containing higher than $45 \mathrm{mg} / \mathrm{L}$ of nitrate can lead to human health problems (BIS 2012). However, Adimalla et al. (2018c) categorized water based on nitrate concentration in groundwater as being low health risk when nitrate values less the $45 \mathrm{mg} / \mathrm{L}$, high health risk when value range from 45 to $100 \mathrm{mg} / \mathrm{L}$, very high health risk when values more than $100 \mathrm{mg} / \mathrm{L}$. In the current study, $81 \%, 15 \%$, and $4 \%$ of groundwater samples fall in low health risk, high health risk, and very high health risk category, respectively (Fig. 2). Therefore, the high concentration of nitrate in drinking water is toxic and causes blue baby syndrome/methemoglobinemia in children and gastric carcinomas (Adimalla and Qian 2019b; Adimalla 2019; Adimalla and Li 2018).

\section{Fluoride geochemistry}

Fluorine is the most electronegative of all elements and occurs primarily as a negatively charged ion in water (Hem 1991; Adimalla et al. 2018a, c). Intake of small concentration is beneficial for human health. However, in the present study area, the concentration of fluoride ranged from 0.4 to $5.8 \mathrm{mg} / \mathrm{L}$ with a mean of $1.98 \mathrm{mg} / \mathrm{L}$ (Tables 1 and 2 ), which indicates that the concentration of fluoride is not uniform in the study area. For example, the fluoride 


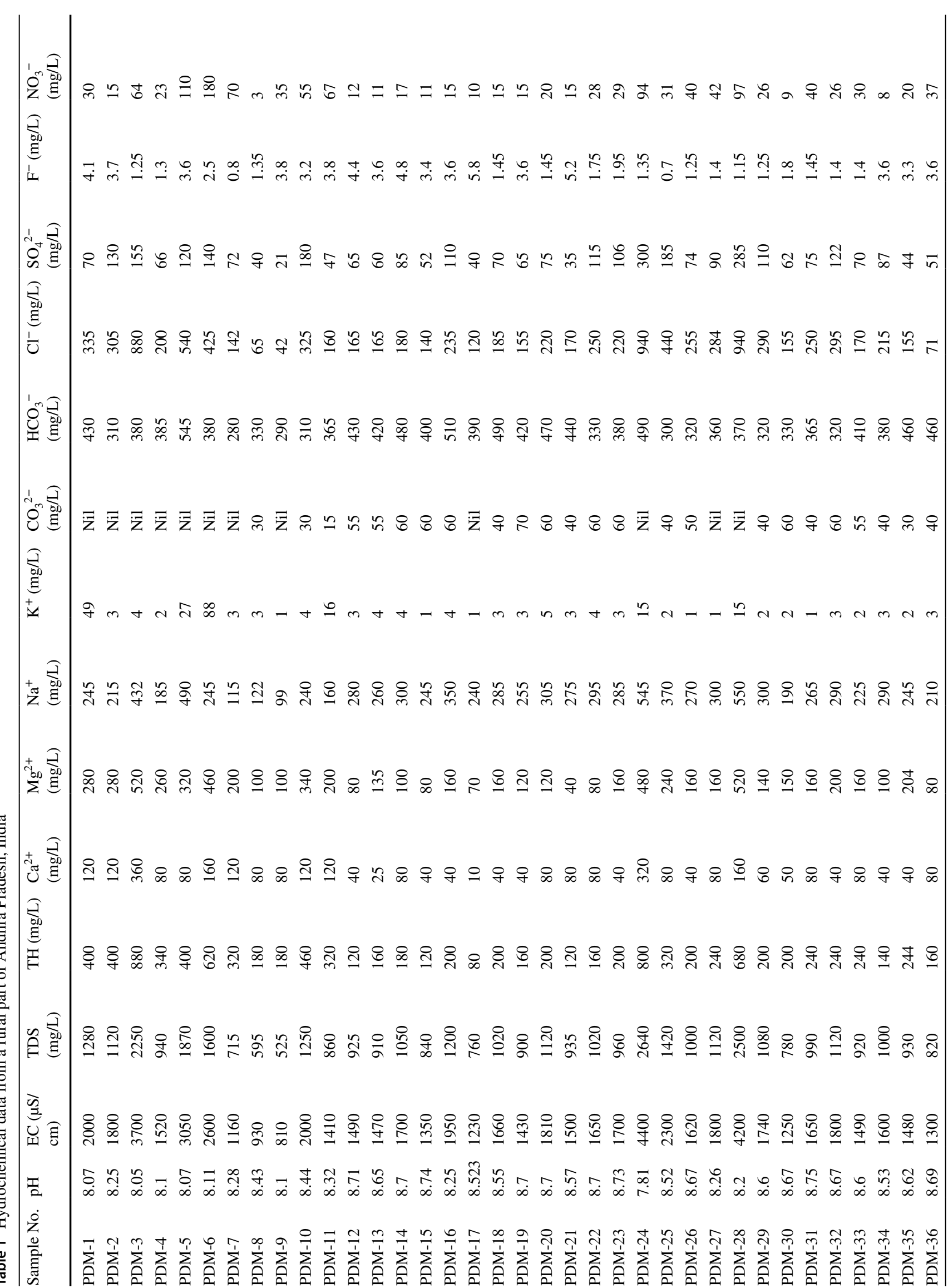




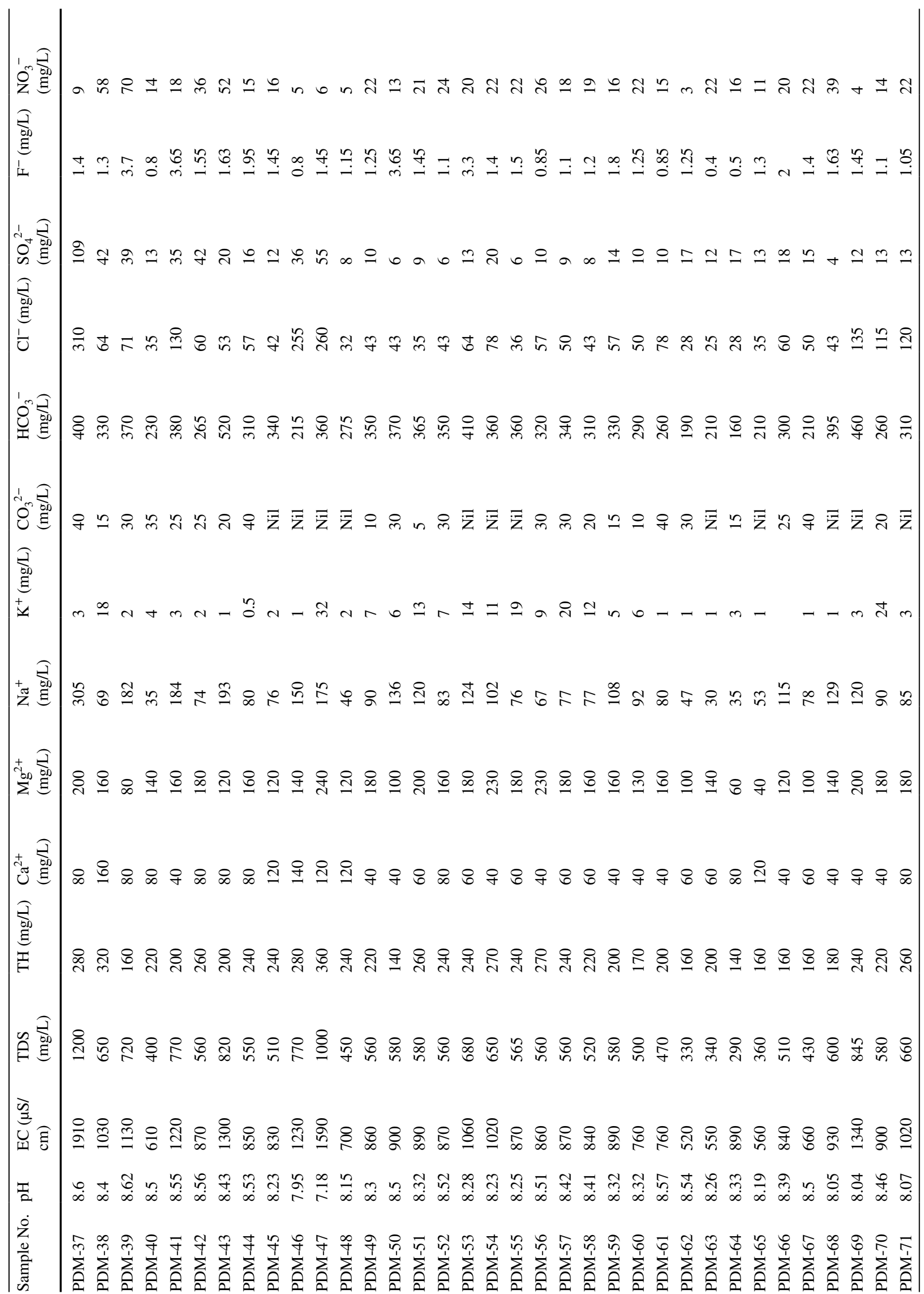




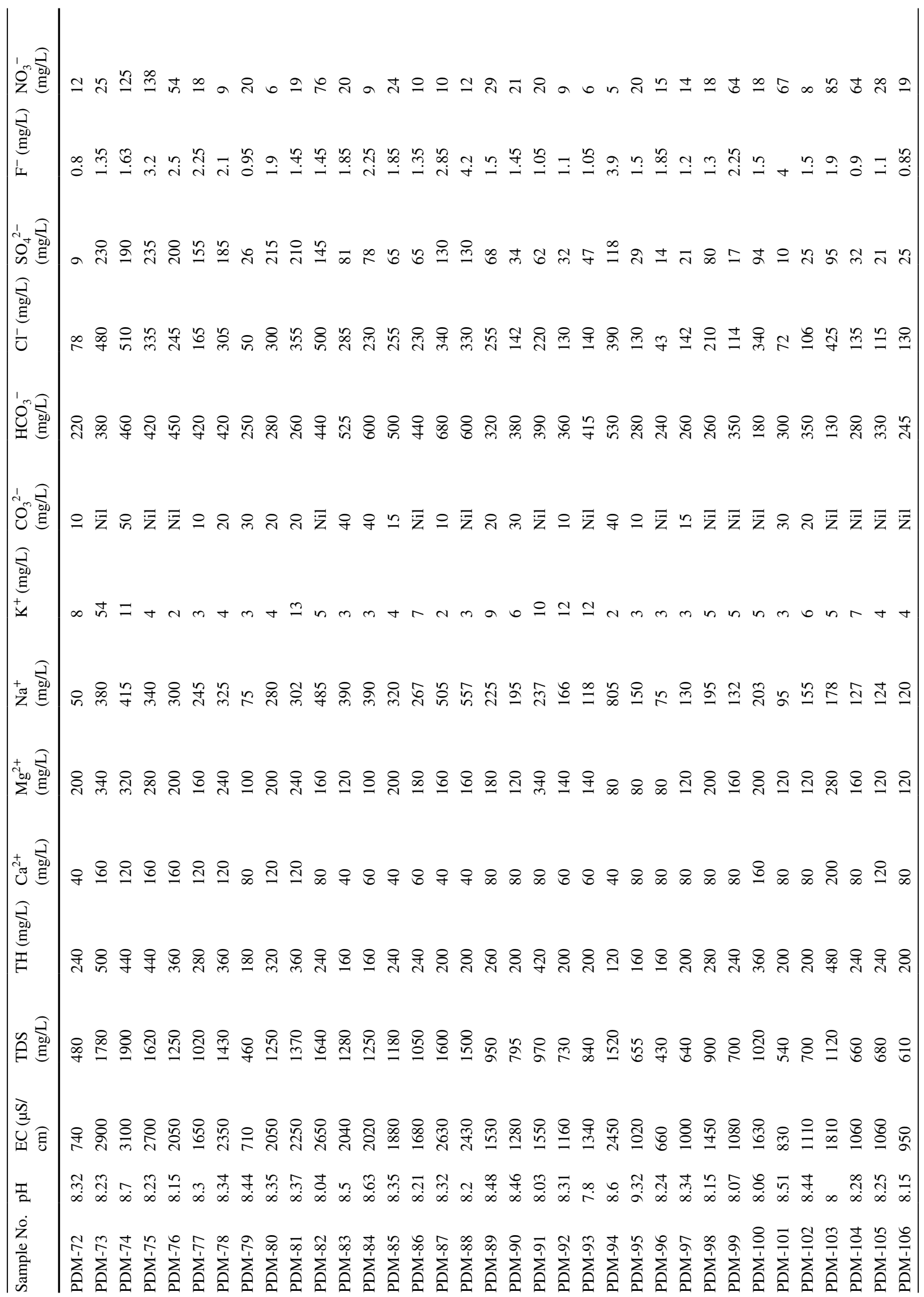




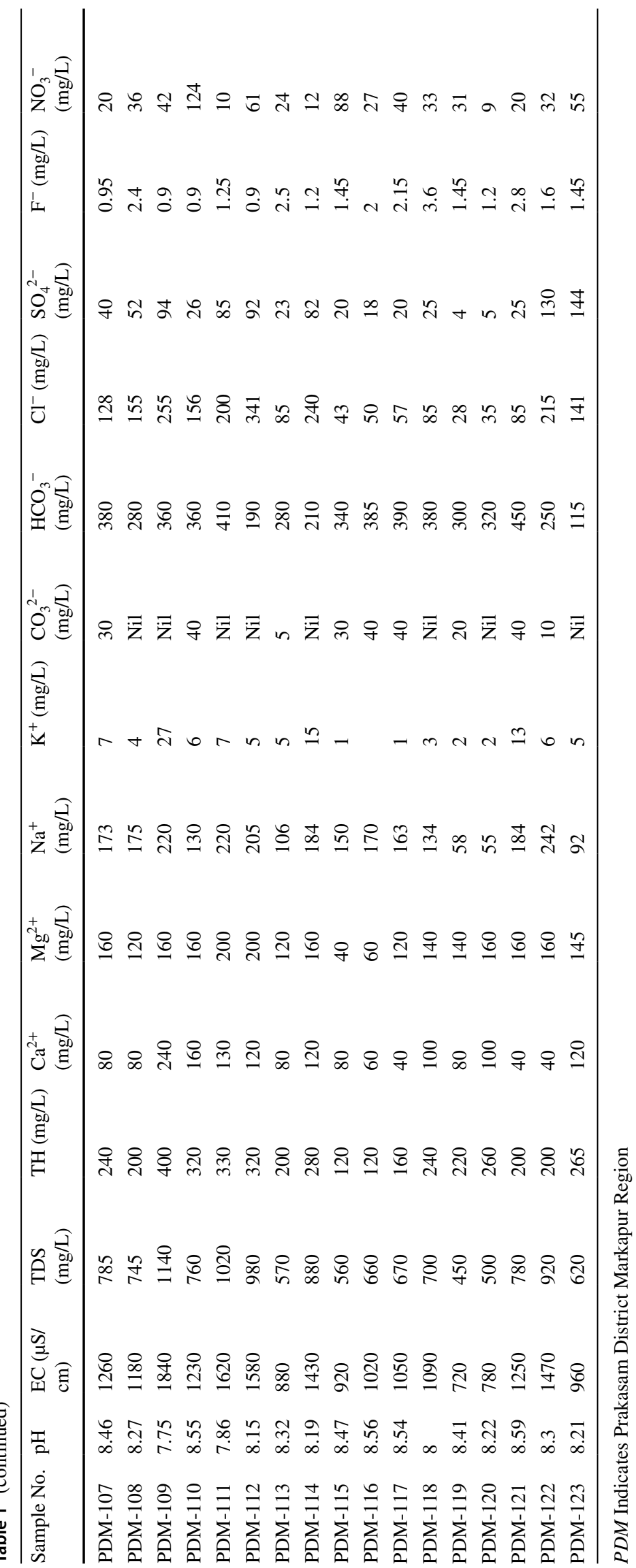


Table 2 Groundwater samples from a rural part of Andhra Pradesh, India exceeding the permissible limits prescribed by WHO (2004) and ISI (1993) for drinking purpose

\begin{tabular}{|c|c|c|c|c|c|}
\hline \multirow[t]{2}{*}{$\begin{array}{l}\text { Water quality } \\
\text { parameters }\end{array}$} & \multicolumn{2}{|c|}{ Indian Standard (ISI 10500, 1993) } & \multicolumn{2}{|c|}{$\begin{array}{l}\text { WHO International Stand- } \\
\text { ards (2004) }\end{array}$} & \multirow{2}{*}{$\begin{array}{l}\text { Range in the } \\
\text { Markapur } \\
\text { region }\end{array}$} \\
\hline & Highest desirable & Max. permissible & $\begin{array}{l}\text { Most desir- } \\
\text { able limit }\end{array}$ & $\begin{array}{l}\text { Max. allow- } \\
\text { able limit }\end{array}$ & \\
\hline $\mathrm{pH}$ & $6.5-8.5$ & $6.5-9.5$ & 6.5 & 8.5 & $7.18-9.32$ \\
\hline $\mathrm{EC}$ & - & - & 1400 & - & $520-4400$ \\
\hline TDS & 500 & 2000 & 500 & 1500 & $290-2640$ \\
\hline $\mathrm{TH}$ & 300 & 600 & 100 & 500 & $80-880$ \\
\hline $\mathrm{CO}_{3}{ }^{2-}$ & - & - & - & - & $5-70$ \\
\hline $\mathrm{HCO}_{3}^{-}$ & - & - & - & - & $115-680$ \\
\hline $\mathrm{Cl}^{-}$ & 250 & 1000 & 200 & 600 & $25-940$ \\
\hline $\mathrm{NO}_{3}^{-}$ & - & 45 & - & 45 & $3-180$ \\
\hline $\mathrm{F}^{-}$ & 0.6 & 1.2 & 0.5 & 1.5 & $0.4-5.8$ \\
\hline $\mathrm{Ca}^{2+}$ & 75 & 200 & 75 & 200 & $10-360$ \\
\hline $\mathrm{Mg}^{2+}$ & 30 & 100 & 50 & 150 & $40-520$ \\
\hline $\mathrm{K}^{+}$ & - & - & - & 12 & $0.5-88$ \\
\hline $\mathrm{Na}^{+}$ & - & 200 & - & 200 & $30-805$ \\
\hline
\end{tabular}

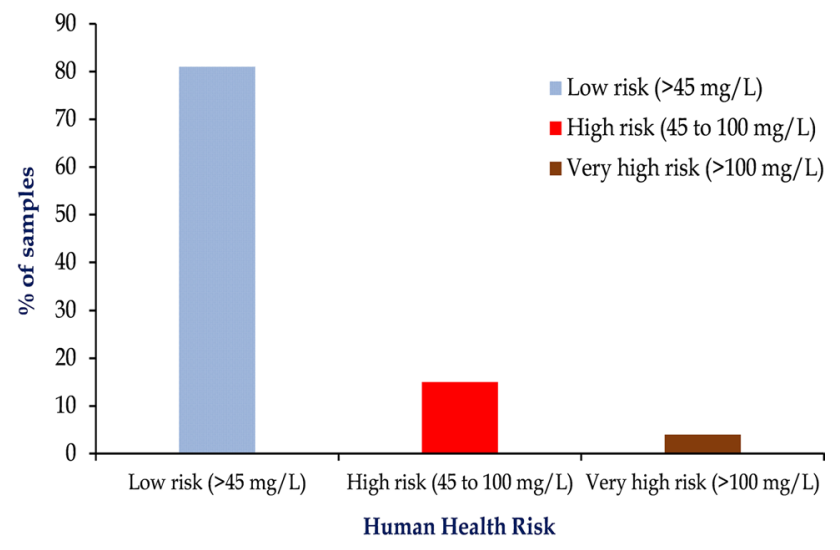

Fig. 2 Distribution of nitrate and its health risk classification in the study area

content varies from 0.4 to $1.0 \mathrm{mg} / \mathrm{L}$ in $13 \%$ of the groundwater samples, 1.1 to $1.5 \mathrm{mg} / \mathrm{L}$ in $49 \%$ of the groundwater; 1.6 to $2.9 \mathrm{mg} / \mathrm{L}$ in $23 \%$ of the groundwater; and 3.2 to $5.8 \mathrm{mg} / \mathrm{L}$ in $21 \%$ of the groundwater samples in the study region (Tables 1 and 2) and it also confirmed from the distribution map of fluoride (Fig. 3). It is clear from the distribution map of fluoride that except for extreme northern and southern parts of the study area, all other areas have excess fluoride (Fig. 3). The highest fluoride concentration is noticed in the west-central part of the area. However, fluoride can gain entry into the human body through different routes, probable transmission routes, and its health effects are shown in Fig. 4. WHO (2004) has prescribed the desirable and maximum allowable limits of fluoride as 1.0 and $1.5 \mathrm{mg} / \mathrm{L}$, respectively, in drinking water. Moreover, United States Public Health Services (US PHS 1987)

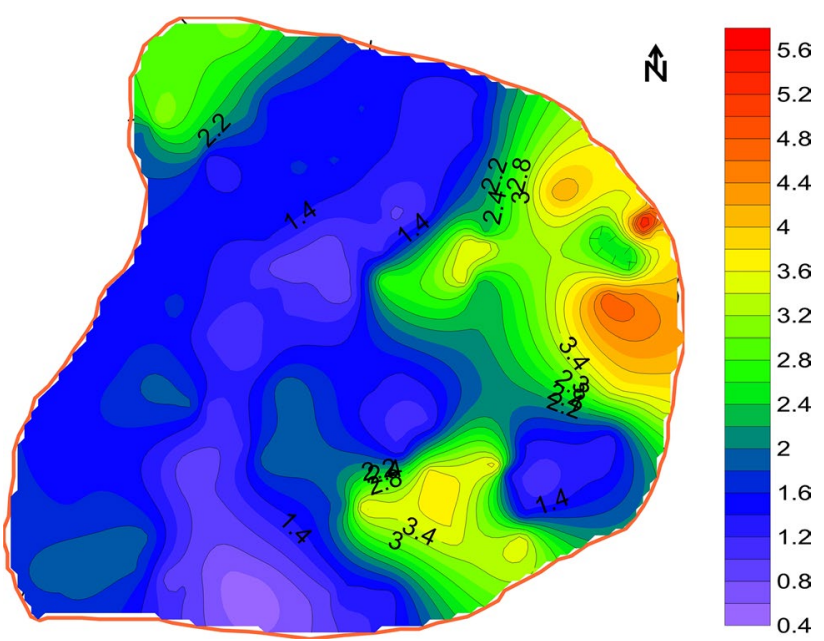

Fig. 3 Distribution of fluoride concentration in the groundwater of the study area

observed that the recommended limit of fluoride in the drinking water majorly relies on the climatic conditions of the region. Therefore, in the Indian context, the desirable and maximum allowable limit of fluoride in drinking water is fixed as 0.6 to $1.2 \mathrm{mg} / \mathrm{L}$, respectively (BIS 2012). If fluoride concentration less than $0.6 \mathrm{mg} / \mathrm{L}$ can cause dental caries, while higher than $1.2 \mathrm{mg} / \mathrm{L}$ leads to fluorosis. Based on these limits, it is noticed that the fluoride concentration of groundwater in the study region is 4.83 times higher than the $1.2 \mathrm{mg} / \mathrm{L}$ (BIS 2012). However, Dissanayake (1991) categorized drinking water based on fluoride classification as being conducive to dental caries when fluoride concentration is less than $0.5 \mathrm{mg} / \mathrm{L}$, promotes development of strong bones, when the concentration ranged 


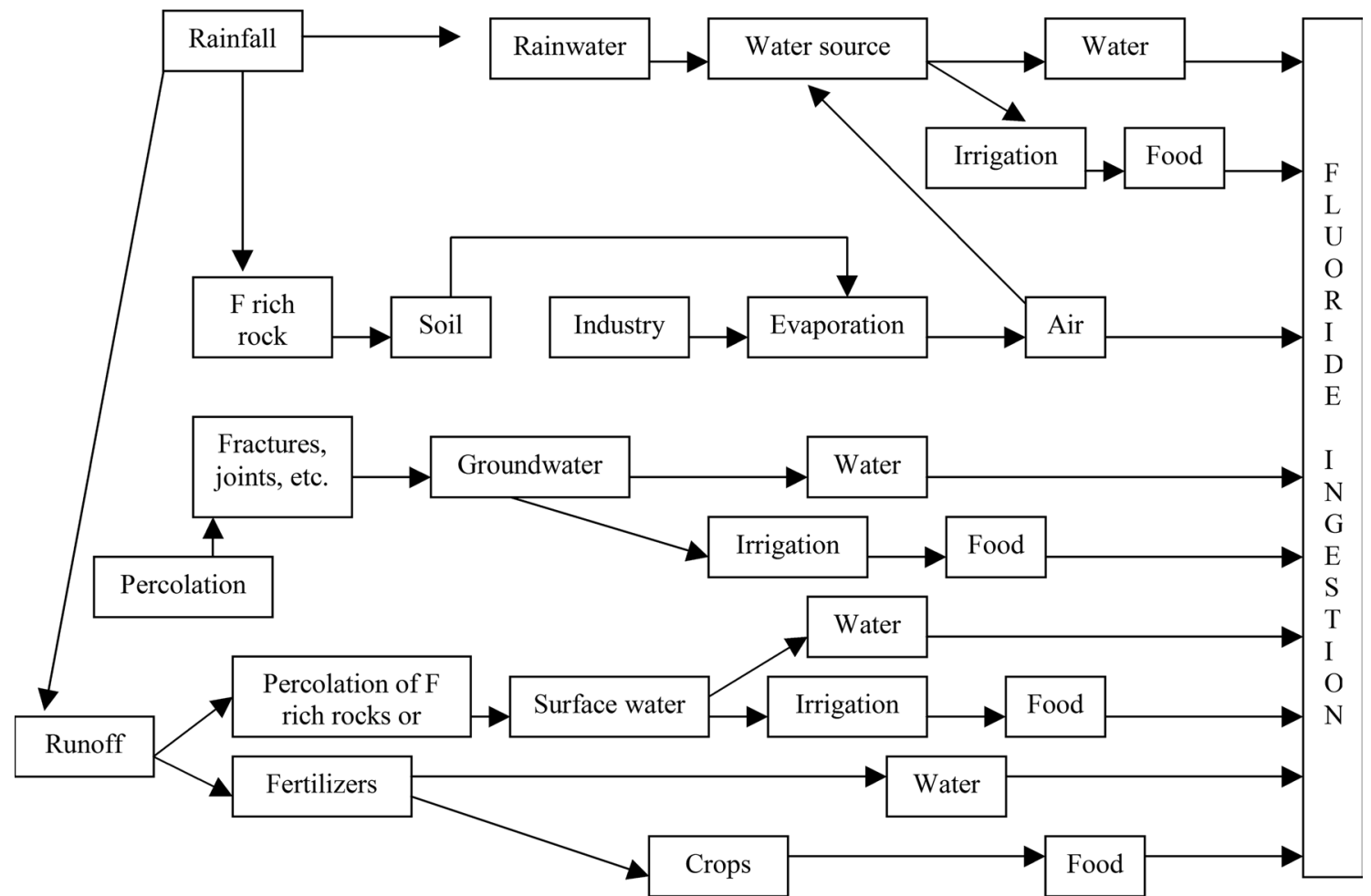

Fig. 4 Probable transmission routes of fluoride ingestion

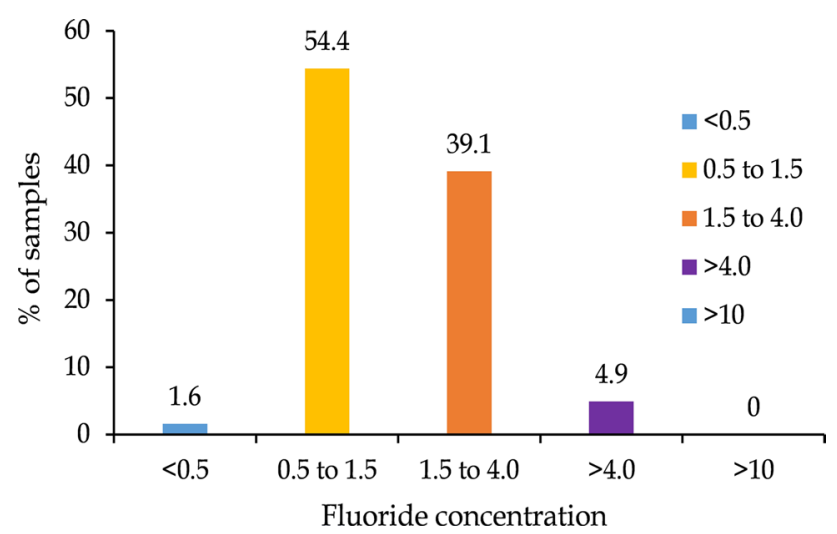

Fig. 5 Fluoride classification in the groundwater of Markapur region, India

between 0.5 and $1.5 \mathrm{mg} / \mathrm{L}$, promotes dental fluorosis in children, when fluoride concentration ranged from 1.5 to $4.0 \mathrm{mg} / \mathrm{L}$, and promotes dental and skeletal fluorosis when its concentration is greater than $4.0 \mathrm{mg} / \mathrm{L}$, respectively. As shown in Fig. 5, fluoride classification, $1.6 \%$ and $54.4 \%$ of groundwater samples are conducive to dental caries and promote the development of strong bones and teeth category, respectively, while $39.1 \%$ and $4.9 \%$ of groundwater samples promote dental fluorosis in children and promote dental and skeletal fluorosis category, respectively (Fig. 5, Table 3).
Table 3 Effects of fluoride ingestion on human health Dissanayake (1991)

\begin{tabular}{ll}
\hline $\begin{array}{l}\text { Fluoride concen- } \\
\text { tration }(\mathrm{mg} / \mathrm{L})\end{array}$ & Effect on human health \\
\hline$<0.5$ & Conducive to dental caries \\
0.5 to 1.5 & Promotes development of strong bones and teeth \\
1.5 to 4.0 & Promotes dental fluorosis in children \\
$>4.0$ & Promotes dental and skeletal fluorosis \\
$>10$ & Crippling skeletal fluorosis, possibly cancer
\end{tabular}

\section{Correlation of fluoride with other parameters}

For understanding the relation between fluoride and other chemical parameters, correlation plots provide significant geochemical information and also help to know the controlling factors and its mechanism of fluoride enrichment in the groundwater (Adimalla et al. 2018a; Wu et al. 2019). A moderate positive correlation is observed between fluoride and pH (Fig. 6a) which indicates that the higher alkaline nature of water accelerates the enrichment of fluoride concentration and thus typically affects the concentration of fluoride in the groundwater (Narsimha and Sudarshan 2017a, b, 2018a, b; Narsimha and Rajitha 2018). A significant positive correlation is noticed between fluoride with bicarbonate (Fig. 6b) and also fluoride with sodium (Fig. 6c), which declares that 

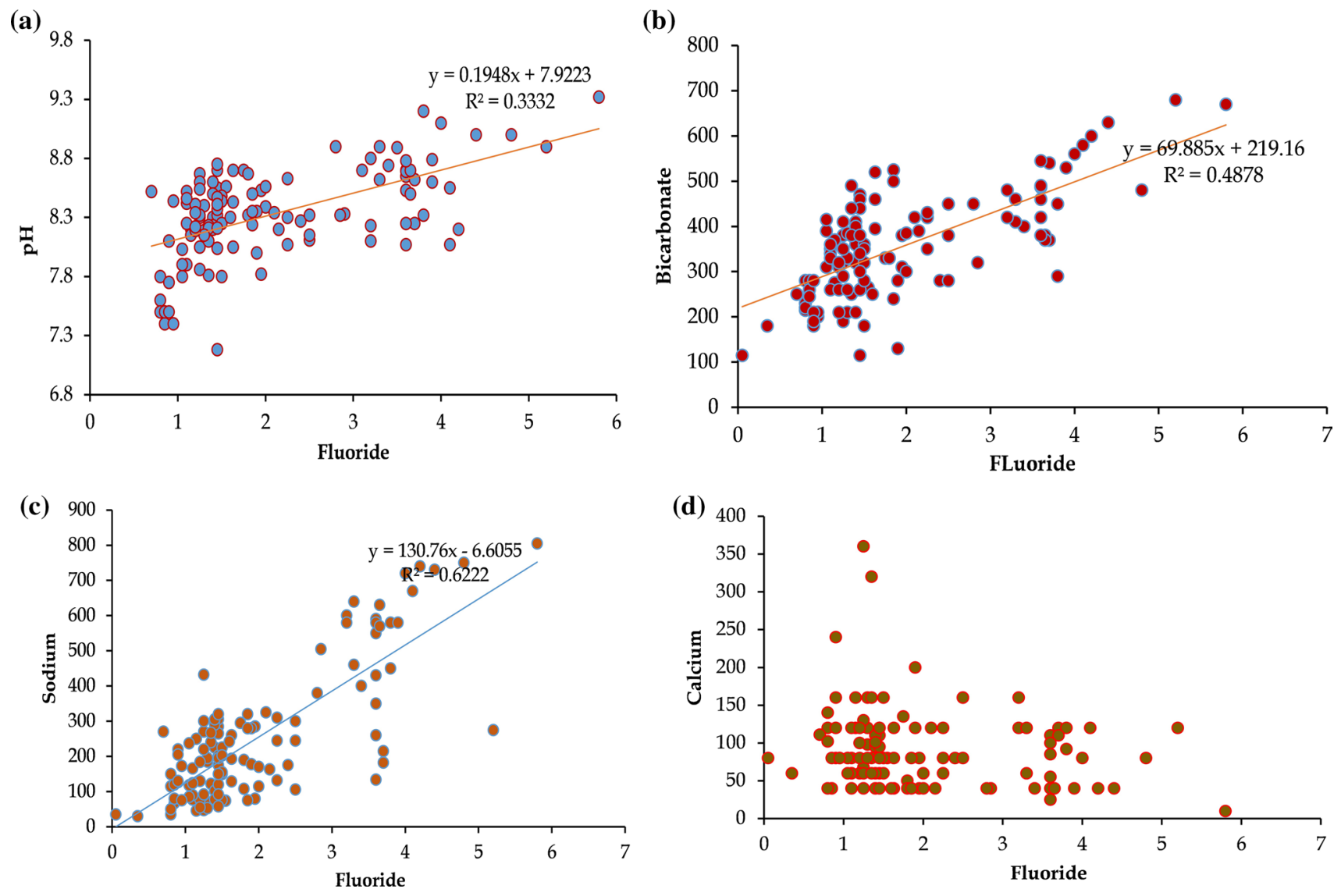

Fig. 6 Correlation between a fluoride and $\mathrm{pH}, \mathbf{b}$ fluoride and bicarbonate, $\mathbf{c}$ fluoride and sodium, and $\mathbf{d}$ fluoride and calcium in the groundwater of Markapur, India

the alkaline environment is the dominant controlling chemical mechanism for leaching of fluoride from the fluoridebearing minerals in the groundwater of the study region (Adimalla et al. 2018a; Li et al. 2018; Subbarao et al. 2017; Ayoob and Gupta 2006). Moreover, as shown in Fig. 6d, the correlation of fluoride and calcium, this clearly indicates that the presence of high calcium content favored low fluoride concentration in the groundwater. It is observed that the major role of precipitation process that is a vital mechanism for enhancement of fluoride occurrence in groundwater (Adimalla et al. 2018a; Narsimha and Sudarshan 2017b, 2018a, b; Li et al. 2018) and negative relations of fluoride with magnesium (Supplementary Fig. 1) is an agreement as established by Reddy et al. 2016. A number of studies have demonstrated that the positive correlations between fluoride and both $\mathrm{pH}$, bicarbonate and sodium typically accelerate the fluoride concentration in groundwater as well as an inverse relationship between fluoride and calcium, which reveals the concentration in fluorite saturated groundwater (Adimalla and Venkatayogi 2017; Adimalla et al. 2018a, b; Ayoob and Gupta 2006; Narsimha and Sudarshan 2017a, b; Narsimha and Rajitha 2018). However, Fig. 7a, b reveals that the high concentration of EC and TDS is always linked with greater fluoride concentration and the similar observations noticed in different regions (Adimalla et al. 2018a; Subba rao et al. 2015; Adimalla and Venkatayogi 2018, 2017; Narsimha 2018; Narsimha and Sudarshan 2013). Moreover, EC and TDS correlation with fluoride is not as high as $\mathrm{pH}$, bicarbonate, and sodium in the study area, which divulges that a higher affinity of fluoride with $\mathrm{pH}$ and bicarbonate rather than EC and TDS. However, there is no significant relationship existed between fluoride and $\mathrm{SO}_{4}{ }^{2-}, \mathrm{Cl}^{-}$, and $\mathrm{K}^{+}$(Supplementary Fig 1), which revealed that the ionic concentrations added into groundwater is not from similar sources. Furthermore, it is indicated that no considerable relation exists between $\mathrm{F}^{-}$and $\mathrm{NO}_{3}{ }^{-}$(Fig. 8) as these elements are added to groundwater from dissimilar sources, $\mathrm{F}^{-}$from geogenic and $\mathrm{NO}_{3}{ }^{-}$from anthropogenic sources.

\section{Groundwater types}

Piper Trilinear diagram (Piper 1953) is one of the most widely applied methods for characterizing groundwater type. Therefore, analysis data were plotted on Piper (Piper

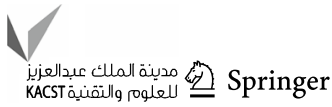



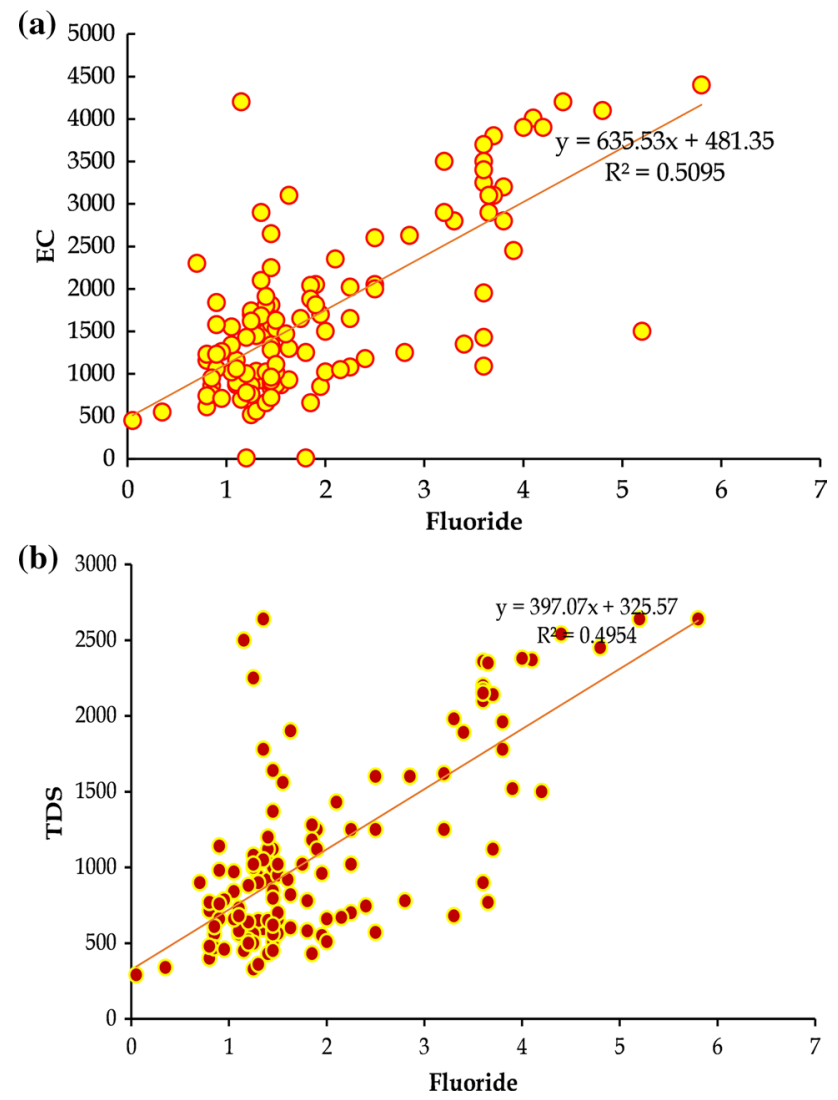

Fig. 7 Correlation between a fluoride and EC, and $\mathbf{b}$ fluoride and TDS in the groundwater of Markapur, India

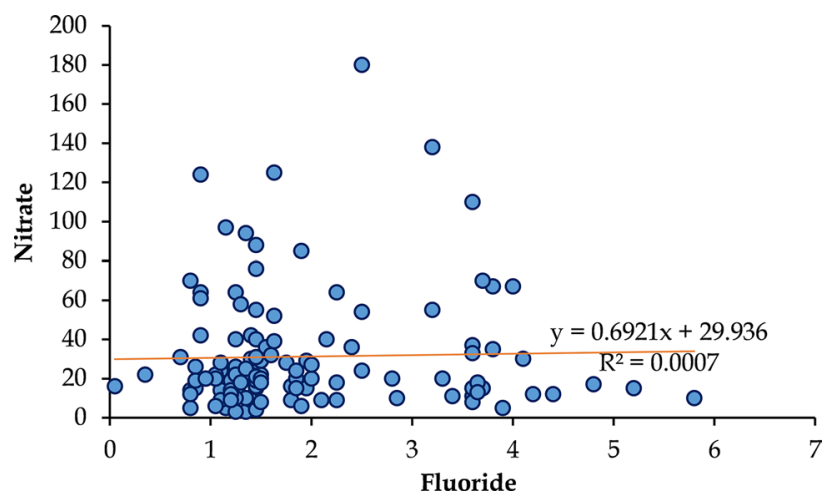

Fig. 8 Correlation between fluoride and nitrate in the groundwater of Markapur, India

1953) and depicted in Fig. 9. It categorized the groundwater into four types which are (1) $\mathrm{Ca}^{2+}-\mathrm{mg}^{2+}-\mathrm{HCO}_{3}{ }^{-}$, (2) $\mathrm{Na}^{+}-\mathrm{K}^{+}-\mathrm{HCO}_{3}^{-}$, (3) $\mathrm{Ca}^{2+}-\mathrm{mg}^{2+}-\mathrm{Cl}^{-}-\mathrm{SO}_{4}{ }^{2-}$, and (4) $\mathrm{Na}^{+}-\mathrm{K}^{+}-\mathrm{Cl}^{-}-\mathrm{SO}_{4}{ }^{2-}$ (Li et al. 2016a, b). Results are shown in Fig. 9 and observed that most of the groundwater samples fall in the area $\mathrm{Ca}^{2+}-\mathrm{mg}^{2+}-\mathrm{HCO}_{3}{ }^{-}(54 \%)$, $\mathrm{Na}^{+}-\mathrm{K}^{+}-\mathrm{HCO}_{3}{ }^{-}(34 \%)$, and $\mathrm{Ca}^{2+}-\mathrm{mg}^{2+}-\mathrm{Cl}^{-}-\mathrm{SO}_{4}{ }^{2-}(15 \%)$

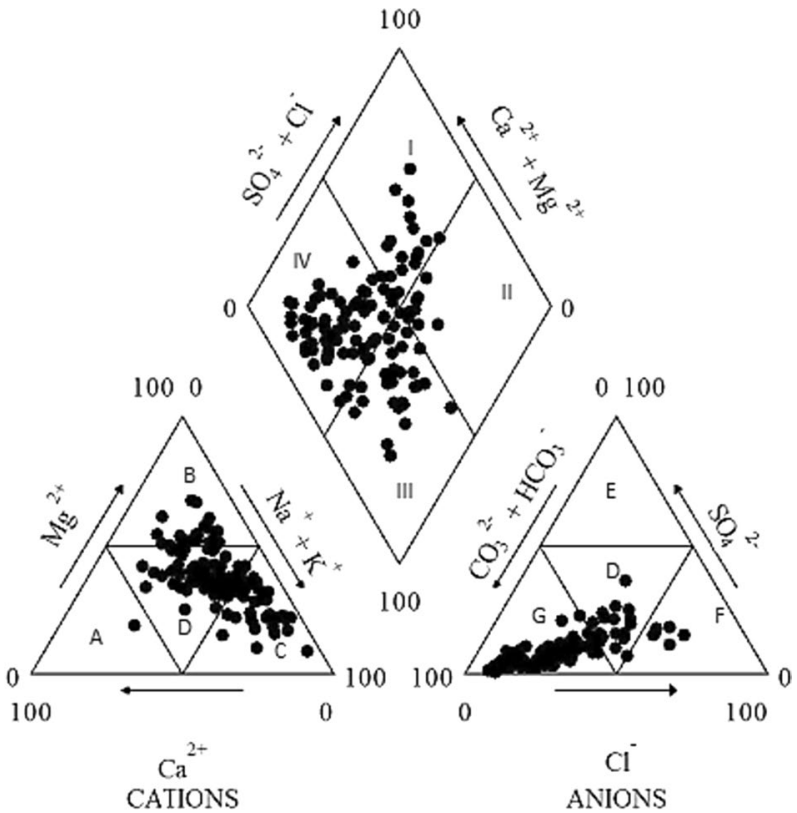

A. Calcium, B. Magnesium, C. Sodium, D. No Dominant, E. Sulphate, F. Chloride, G. Bicarbonate; I. Ca-Mg-Cl-SO4, II. Na-K-Cl-SO4, III. Na-K-HCO3, IV. Ca-Mg-HCO3

Fig. 9 Hydrogeochemical classification of the groundwater samples from the Markapur region, Prakasam district, Andhra Pradesh, India

which are the major water types, and few groundwater samples are plotted in $\mathrm{Na}^{+}-\mathrm{K}^{+}-\mathrm{Cl}^{-}-\mathrm{SO}_{4}{ }^{2-}(7 \%)$. However, as discussed above, fluoride is shown significant correlations with bicarbonate and sodium (Fig. 6b, c). Based on this observation, fluoride concentration is quite high in $\mathrm{Na}^{+}-\mathrm{HCO}_{3}{ }^{-}$type of water compared with $\mathrm{Ca}^{2+}-\mathrm{HCO}_{3}{ }^{-}$or mixed $\left(\mathrm{Ca}^{2+}-\mathrm{mg}^{2+}-\mathrm{HCO}_{3}{ }^{-}\right)$-type water (Fig. 9). Moreover, $34 \%$ of groundwater samples are found under $\mathrm{Na}^{+}-\mathrm{HCO}_{3}{ }^{-}$or mixed type $\left(\mathrm{Na}^{+}-\mathrm{K}^{+}-\mathrm{HCO}_{3}^{-}\right)$and cause favor to fluoride dissolution in the study region. A number of previous studies suggested that the $\mathrm{Na}^{+}-\mathrm{HCO}_{3}{ }^{-}$water type, decreasing calcium concentration, increasing sodium concentration, and neutral-to-alkaline $\mathrm{pH}$ nature of water are more favorable for fluoride dissolution process, thereby accelerating the fluoride concentration in groundwater (Rao et al. 2017; Ali et al. 2016; Adimalla et al. 2018a, b; Narsimha and Sudarshan 2017b). Moreover, $\mathrm{Na}^{+}-\mathrm{HCO}_{3}{ }^{-}$water type, mainly deeper groundwater, is influenced by the ion exchange process (Saxena and Ahmed 2003).

$\mathrm{CaF}_{2}+2 \mathrm{NaHCO}_{3} \rightarrow \mathrm{CaCO}_{3}+2 \mathrm{Na}^{+}+2 \mathrm{~F}^{-}+\mathrm{H}_{2} \mathrm{O}+\mathrm{CO}_{2}$

Therefore, the possible above ion exchange processes can accelerate and influence the fluoride solubility in the groundwater, which chiefly reveals that the presence of excessive $\mathrm{Na}^{+}-\mathrm{HCO}_{3}{ }^{-}$in groundwater leads to dissociation activity of fluoride and can be higher in a high alkaline condition 
(Saxena and Ahmed 2003; Adimalla and Venkatayogi 2017; Adimalla et al. 2018a; Li et al. 2014).

\section{Mechanism of rock dominance}

Gibbs (1970) proposed a diagram to understand the relationship of chemical components of waters from their respective aquifer lithologies. The chemical data of groundwater samples from Markapur, South India, were plotted in the Gibbs (1970) diagram (Fig. 10), using Eqs. 2 and 3, where all ionic concentrations are in meq/L.

Gibbs ratio-I (for anions) $=\frac{\mathrm{Cl}^{-}}{\left(\mathrm{Cl}^{-}+\mathrm{HCO}_{3}^{-}\right)}$

Gibbs ratio-II (for cations) $=\frac{N a^{+}}{\left(N a^{+}+C a^{2+}\right)}$

Gibbs diagram (Fig. 10) revealed that the most of the groundwater samples fall under the rock dominance, which typically originates from the weathering of the bedrocks which is a vital process to accelerate the fluoride concentration in groundwater ( $\mathrm{Li}$ et al. 2016a, b; Adimalla and $\mathrm{Wu}$ 2019) and also (Fig. 10) groundwater samples end up with evaporation process of water chemistry, and finally, none of the sampling points lie in the precipitation dominance (Fig. 10). It mostly comes from igneous and sedimentary rocks in different aquifers, where fluoride-bearing minerals occur. These are the source of fluoride especially in India where longer water-rock interaction with aquifer materials and alkaline water activates leaching process in fractured zones and fluctuation zone (Kumar et al. 2014; Narsimha and Sudarshan 2013, 2017a, b, 2018a, b). Similar investigations using the Gibbs diagram such as Adimalla et al. (2018a) have found that elevated concentrations of fluoride are associated with groundwater that plots in the "rock dominance" field in a Gibbs diagram. Similarly, observations were noticed in Kolar and Tumkur Districts of Karnataka (Mamatha and Rao 2010), Chirala and Ongole of Andhra Pradesh (Subba Rao et al. 2015; Rao et al. 2017), and Chimakurthy pluton, Prakasam District, Andhra Pradesh (Reddy et al. 2016). However, it is also supported by the existing negative correlation between fluoride and nitrate (Fig. 8), which indicates that the elevated fluoride comes through the water-rock interaction, not by the anthropogenic sources.

\section{Conclusions}

Geochemical behavior and controlling factors of fluoride in groundwater of Markapur area, Andhra Pradesh, are studied and assessed. The following conclusions were drawn:

- The fluoride concentrations varied from 0.4 to $5.8 \mathrm{mg} / \mathrm{L}$, and it is clear that the level of fluoride is higher in 54 groundwater locations than that of recommended upper limit by WHO and by Bureau of Indian Standards.

- Evaluation of the hydrogeochemical facies in the groundwater revealed that $54 \%$ and $34 \%$ of samples belong to (a)

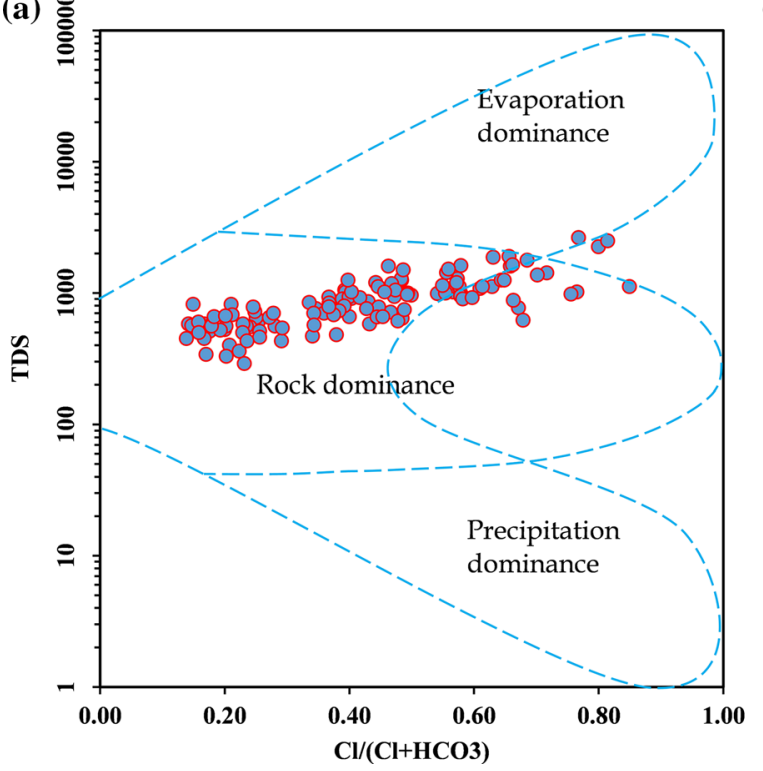

(b)

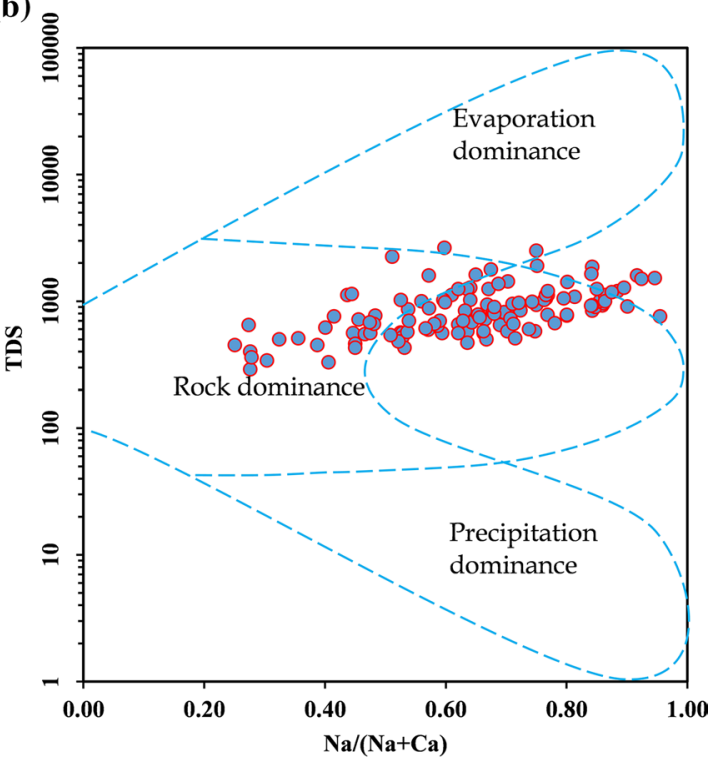

Fig. 10 Gibbs diagram, illustrating the mechanisms controlling the chemistry of groundwater samples from Markapur, Prakasam district, Andhra Pradesh, India 
the $\mathrm{Ca}^{2+}-\mathrm{HCO}_{3}{ }^{-}$or mixed $\mathrm{Ca}^{2+}-\mathrm{Mg}^{2+}-\mathrm{HCO}_{3}{ }^{-}, \mathrm{Na}^{+}-$ $\mathrm{HCO}_{3}{ }^{-}$water types, whereas high fluoride concentration belongs to majorly $\mathrm{Na}^{+}-\mathrm{HCO}_{3}{ }^{-}$water type and relatively low concentrations in $\mathrm{Na}^{+}-\mathrm{K}^{+}-\mathrm{Cl}^{-}-\mathrm{SO}_{4}{ }^{2-}$ water type in Markapur region.

- Furthermore, rock-water interaction, mixing process of aquifer, and dissolution of minerals have affected the hydrogeochemical characteristics. Therefore, the reason of high fluoride in the study region is due to rock-water interactions, deficiency of calcium, and alkaline nature of water.

- Most of the people in the area depend on groundwater for their daily needs, without any primary treatment and actually they do not know much about the quality of groundwater and hence, people suffer from the dental and bone fluorosis in their lifetime.

- It is recommended to avoid high fluoride groundwater and depend on alternate sources. It is suggested that rainwater harvesting is one of the ways to dilute the fluoride concentrations in groundwater and helps to avoid excessive fluoride intake in the present study region.

Acknowledgements The authors are highly thankful to the Editors and anonymous reviewers for their comprehensive comments and suggestions which greatly helped us to improve the quality of the manuscript.

\section{Compliance with ethical standards}

Conflict of interest The authors declare that there is no conflict of interests regarding the publication of this paper.

Open Access This article is distributed under the terms of the Creative Commons Attribution 4.0 International License (http://creativeco mmons.org/licenses/by/4.0/), which permits unrestricted use, distribution, and reproduction in any medium, provided you give appropriate credit to the original author(s) and the source, provide a link to the Creative Commons license, and indicate if changes were made.

\section{References}

Adimalla N (2018) Groundwater quality for drinking and irrigation purposes and potential health risks assessment: a case study from semi-arid region of South India. Exposure Health. https://doi. org/10.1007/s12403-018-0288-8

Adimalla N (2019) Spatial distribution, exposure, and potential health risk assessment from nitrate in drinking water from semi-arid region of South India. Hum Ecol Risk Assess Int J. https://doi. org/10.1080/10807039.2018.1508329

Adimalla N, Li P (2018) Occurrence, health risks, and geochemical mechanisms of fluoride and nitrate in groundwater of the rockdominant semi-arid region, Telangana State, India. Hum Ecol Risk Assess Int J. https://doi.org/10.1080/10807039.2018.14803 53

Adimalla N, Qian H (2019a) Hydrogeochemistry and fluoride contamination in the hard rock terrain of central Telangana, India: analyses of its spatial distribution and health risk. SN Appl Sci 1(3):202. https://doi.org/10.1007/s42452-019-0219-8

Adimalla N, Qian H (2019b) Groundwater quality evaluation using water quality index (WQI) for drinking purposes and human health risk (HHR) assessment in an agricultural region of Nanganur, south India. Ecotoxicol Environ Saf 176:153-161. https:// doi.org/10.1016/j.ecoenv.2019.03.066

Adimalla N, Venkatayogi S (2017) Mechanism of fluoride enrichment in groundwater of hard rock aquifers in Medak, Telangana State, South India. Environ Earth Sci 76:45. https://doi.org/10.1007/ s12665-016-6362-2

Adimalla N, Venkatayogi S (2018) Geochemical characterization and evaluation of groundwater suitability for domestic and agricultural utility in semi-arid region of Basara, Telangana State, South India. Appl Water Sci 8:44. https://doi.org/10.1007/s13201-018-0682-1

Adimalla N, Wu J (2019) Groundwater quality and associated health risks in a semi-arid region of south India: Implication to sustainable groundwater management. Hum Ecol Risk Assess Int J 7:1-26. https://doi.org/10.1080/10807039.2018.1546550

Adimalla N, Vasa SK, Li P (2018a) Evaluation of groundwater quality, Peddavagu in Central Telangana (PCT), South India: an insight of controlling factors of fluoride enrichment model. Earth Syst Environ 4(2):841-852. https://doi.org/10.1007/s40808-018-0443-z

Adimalla N, Li P, Venkatayogi S (2018b) Hydrogeochemical evaluation of groundwater quality for drinking and irrigation purposes and integrated interpretation with water quality index studies. Environ Process 5(2):363-383. https://doi.org/10.1007/s4071 0-018-0297-4

Adimalla N, Li P, Qian H (2018c) Evaluation of groundwater contamination for fluoride and nitrate in semi-arid region of Nirmal Province, South India: a special emphasis on human health risk assessment (HHRA). Hum Ecol Risk Assess Int J. https://doi. org/10.1080/10807039.2018.1460579

Ali S, Thakur SK, Sarkar A, Shekhar S (2016) Worldwide contamination of water by fluoride. Environ Chem Lett 14(3):291-315

Anim-Gyampo M, Anornu GK, Appiah-Adjei EK, Agodzo SK (2018) Hydrogeochemical evolution and quality assessment of groundwater within the Atankwidi basin: the case of northeastern Ghana. Arab J Geoscin 11:439. https://doi.org/10.1007/s1251 7-018-3753-6

APHA (1995) Standard methods for the examination of water and wastewater, 19th edn. APHA, Washington DC

Ayoob S, Gupta AK (2006) Fluoride in drinking water: a review on the status and stress effects. Crit Rev Environ Sci Technol 36:433-487

BIS (2012) Indian standard specification for drinking water (IS 10500: 2012). BIS (Bureau of Indian Standards), New Delhi, India

CGWB (2013) Groundwater brochure, Prakasam district, Andhra Pradesh (AAP-2012-13). Central Ground Water Board, Southern Region, Hyderabad

Diaz-Barriga F, Leyva R, Quistian J, Loyola-Rodriguez JB, Pozos A, Grimaldo M (1997) Endemic fluorosis in San Luis Potosi, Mexico. Fluoride 30:219-222

Dissanayake CB (1991) The fluoride problem in the ground water of Sri Lanka-environmental management and health. Int J Environ Stud 38(2-3):137-155

Domenico PA, Schwartz FW (1990) Physical and chemical hydrogeology. Wiley, New York, pp 410-420

Gbadebo AM (2012) Groundwater fluoride and dental fluorosis in southwestern Nigeria. Environ Geochem Health 34:597-604

Gibbs RJ (1970) Mechanisms controlling World's water chemistry. Science 170:1088-1090

Gikinju JK, Simiyu KW, Gathura PB, Kyule M, Kanja LW (2002) River water fluoride in Kenya. Res Rep 35(3):193-196

Gizaw B (1996) The origin of high bicarbonate and fluoride concentrations in waters of the main Ethiopian Rift Valley. J Afr Earth Sci 22:391-402 
GSI (1993) Geological map of India on 1: 5 Million Scale. Geological Survey of India, Calcutta, India

GSI-NGRI (2006) Gravity map series of India. Geological Survey of India and National Geophysical Research Institute, Hyderabad

Hem JD (1991) Study and interpretation of the chemical characteristics of natural water. U.S. Geological Survey Water Supply Paper 2254. Scientific Publishers, Jodhpur, India, p 264

ISI (1993) Indian standard specification for drinking water. ISI 10500, New Delhi

Kim K, Jeong YG (2005) Factors influencing natural occurrence of fluoride-rich ground waters: a case study in the southeastern part of the Korean Peninsula. Chemosphere 58:1399-1408

Kumar PJS, Jegathambal P, James EJ (2014) Factors influencing the high fluoride concentration in groundwater of Vellore District, South India. Environ Earth Sci 72:2437-2446

Li P, Qian H, Wu J, Chen J, Zhang Y, Zhang H (2014) Occurrence and hydrogeochemistry of fluoride in shallow alluvial aquifer of Weihe River, China. Environ Earth Sci 71(7):3133-3145. https:// doi.org/10.1007/s12665-013-2691-6

Li P, Zhang Y, Yang N, Jing L, Yu P (2016a) Major ion chemistry and quality assessment of groundwater in and around a mountainous tourist town of China. Expo Health 8(2):239-252. https://doi. org/10.1007/s12403-016-0198-6

Li P, Wu J, Qian H, Zhang Y, Yang N, Jing L, Yu P (2016b) Hydrogeochemical characterization of groundwater in and around a wastewater irrigated forest in the southeastern edge of the Tengger Desert, Northwest China. Expo Health 8(3):331-348. https:// doi.org/10.1007/s12403-016-0193-y

Li P, He X, Li Y et al (2018) Occurrence and health implication of Fluoride in groundwater of Loess aquifer in the Chinese Loess plateau: a case study of Tongchuan. Expo Health, Northwest China. https://doi.org/10.1007/s12403-018-0278-x

Mamatha P, Rao SM (2010) Geochemistry of fluoride rich groundwater in Kolar and Tumkur Districts of Karnataka. Environ Earth Sci 61:131-142

Narsimha A (2018) Elevated fluoride concentration levels in rural villages of Siddipet Telangana State South India. Data in brief 16:693-699. https://doi.org/10.1016/j.dib.2017.11.088

Narsimha A, Rajitha S (2018) Spatial distribution and seasonal variation in fluoride enrichment in groundwater and its associated human health risk assessment in Telangana State, South India. Hum Ecol Risk Assess Int J 24(8):2119-2132. https://doi. org/10.1080/10807039.2018.1438176

Narsimha A, Sudarshan V (2013) Hydrogeochemistry of groundwater in Basara area, Adilabad District, Andhra Pradesh, India. J Appl Geochem 15(2):224-237

Narsimha A, Sudarshan V (2017a) Assessment of fluoride contamination in groundwater from Basara, Adilabad District, Telangana State, India. Appl Water Sci 7(6):2717-2725. https://doi. org/10.1007/s13201-016-0489-x

Narsimha A, Sudarshan V (2017b) Contamination of fluoride in groundwater and its effect on human health: a case study in hard rock aquifers of Siddipet, Telangana State, India. Appl Water Sci 7(5):2501-2512. https://doi.org/10.1007/s13201-016-0441-0

Narsimha A, Sudarshan V (2018a) Drinking water pollution with respective of fluoride in the semi-arid region of Basara, Nirmal district, Telangana State, India. Data Brief 16:752-757. https:// doi.org/10.1016/j.dib.2017.11.087

Narsimha A, Sudarshan V (2018b) Data on fluoride concentration levels in semi-arid region of Medak, Telangana, South India. Data Brief 16:717-723. https://doi.org/10.1016/j.dib.2017.11.089

Piper AM (1953) A graphic procedure in the geological interpretation of water analysis. Groundwater note no. 12, US Geology Survey Department, Washington, DC

Rao PN, Rao AD, Bhargav JS, Siva Sankar K, Sudharshan G (2014) Regional appraisal of the fluoride occurrence in groundwaters of Andhra Pradesh. J Geol Soc India 84:483-493

Rao NS, Rao PS, Dinakar A, Rao PVN, Marghade D (2017) Fluoride occurrence in the groundwater in a coastal region of Andhra Pradesh, India. Appl Water Sci 7(3):1467-1478

Reddy AGS, Reddy DV, Sudheer Kumar M (2016) Hydrogeochemical processes of fluoride enrichment in Chimakurthy pluton, Prakasam district, Andhra Pradesh, India. Environ Earth Sci 75:663

Saxena V, Ahmed S (2003) Inferring the chemical parameters for the dissolution of fluoride in groundwater. Environ Geol 43(6):731-736

Subba Rao N, Vidyasagar G, Surya Rao P, Bhanumurthy P (2015) Assessment of hydrogeochemical processes in a coastal region: application of multivariate statistical model. J Geol Soc India $84: 494-500$

Todd DK (1980) Groundwater hydrology. Wiley Publications, New York

US PHS (1987) Drinking water standards. United States Pubic Health Services Publication, Washington, DC

WHO (1984) Guidelines for drinking water quality, values 3; drinking water quality control in small community supplies. World Health Organisation, Geneva

WHO (2004) World Health Organisation guidelines for drinking water quality, 4th edn. Incorporating the First and Second Addenda, vol. 1 Recommendation, Geneva

Wu J, Sun Z (2016) Evaluation of shallow groundwater contamination and associated human health risk in an alluvial plain impacted by agricultural and industrial activities, mid-west China. Expo Health 8(3):311-329. https://doi.org/10.1007/s12403-015-0170-x

Wu J, Li P, Qian H (2015) Hydrochemical characterization of drinking groundwater with special reference to fluoride in an arid area of China and the control of aquifer leakage on its concentrations. Environ Earth Sci 73(12):8575-8588. https://doi.org/10.1007/ s12665-015-4018-2

Wu J, Li P, Wang D, Ren X, Wei M (2019) Statistical and multivariate statistical techniques to trace the sources and affecting factors of groundwater pollution in a rapidly growing city on the Chinese Loess Plateau. Hum Ecol Risk Assess. https://doi. org/10.1080/10807039.2019.1594156

Publisher's Note Springer Nature remains neutral with regard to jurisdictional claims in published maps and institutional affiliations. 